\title{
PROGRAM KEMITRAAN MASYARAKAT KELOMPOK PEMANFAAT KOTORAN HEWAN (KOHE) DAN KELOMPOK PETANI ORGANIK
}

\author{
(Di Desa Cibodas dan Desa Cisondari, Kecamatan Pasirjambu, Kabupaten Bandung, \\ Provinsi Jawa Barat)
}

\author{
Ratnaningsih Ruhiyat, Dwi Indrawati, Etty Indrawati, Lailatus Siami \\ Fakultas Arsitektur Lanskap dan Teknologi Lingkungan, Universitas Trisakti \\ Jl. Kyai Tapa No.1, Grogol, Jakarta Barat, Indonesia \\ E-mail: ratnaningsih@trisakti.ac.id
}

\begin{abstract}
The Community Partnership Program of Kohe Beneficiary Groups in Cibodas Village and Organic Farmers Group in Cisondari Village, Pasirjambu District, Bandung Regency, is a community service activity aimed at handling cow dung in Cibodas Village, which is currently quite abundant but it has not been well managed, so it has the potential to pollute the environment. The use of cohes uses vermicomposting technology, which results in the form of organic fertilizer known as vermicompost fertilizer. The purpose of this activity was also to introduce vermicomposting technology and familiarize the use of vermicompost fertilizer to organic farmer groups in Cisondari Village, which has been using untreated chicken dung, and the chicken foal is imported from the Tangerang area. The method of implementation includes, socialization and training, polling through questionnaires, vermicomposting demplot and organic farming, focus group discussions and village consultation meetings. The demonstration plot is a field school for kohe managers and organic farmers, so that participants can understand the entire process of the activity. Group discussions are conducted to discuss the results and equate perceptions for all participants in the process of making fertilizers and organic farming. Village consultation activities are intended to convey activities that have been carried out to village heads and community leaders, so that they are expected to have support. Through this activity, cow dung can be used by user groups to become vermicompost with quality that meets quality standards based on Minister of Agriculture Regulation No. 70 / Permentan / SR.140 / 10/2011, and the vermicompost and worm production activities take place so that farmers can provide organic fertilizer and provide additional income for the dung management community.
\end{abstract}

Keywords: animal waste, vermicomposting, organic farming, demonstration plot

\begin{abstract}
Abstrak
Program Kemitraan Masyarakat (PKM) Kelompok Pemanfaat Kohe di Desa Cibodas dan Kelompok Petani Organik di Desa Cisondari, Kecamatan Pasirjambu, Kabupaten Bandung, merupakan kegiatan pengabdian kepada masyarakat yang bertujuan menangani kotoran hewan (kohe) sapi di Desa Cibodas, yang saat ini cukup melimpah jumlahnya namun belum terkelola dengan baik, sehingga berpotensi mencemari lingkungan. Pemanfaatan kohemenggunakan teknologi vermicomposting, yang hasilnya berupa pupuk organik yang dikenal dengan pupuk kascing. Tujuan dari kegiatan ini juga memperkenalkan teknologi vermicomposting dan membiasakan penggunaan pupuk kascing kepada kelompok petani organik di Desa Cisondari, yang selama ini menggunakan kohe ayam tanpa perlakuan, dankohe ayam tersebut didatangkan dari wilayah Tangerang. Metode pelaksanaan meliputi, sosialisasi dan pelatihan, jajak pendapat melalui kuesioner, demplot vermicomposting dan pertanian organik, diskusi kelompok (focus group discussion)serta rembug desa. Demplot merupakan sekolah lapangan bagi pengelola kohe dan petani organik, sehingga pesertadapat memahami seluruh proses kegiatan.Diskusi kelompok dilakukan untuk membahas hasil dan menyamakan persepsi bagi seluruh peserta dalam proses pembuatan pupuk maupun pertanian organik. Kegiatan rembug desa, ditujukan untuk menyampaikan kegiatan yang telah dilakukan kepada kepala desa dan tokoh masyarakat, sehingga diharapkan adanya dukungan dari mereka. Melalui kegiatan ini,kohe sapi dapat dimanfaatkan oleh kelompok pemanfaatmenjadi pupuk kascing dengan kualitas yang memenuhi standar kualitas berdasarkanPeraturan Menteri Pertanian Nomor 70/Permentan/SR.140/10/2011,dan berlangsungnya kegiatan produksi kascing dan cacing, sehingga dapat menyediakan pupuk organik bagi petani dan memberikan tambahan pendapatan bagi masyarakat pengelola kohe.
\end{abstract}

Katakunci: kotoran hewan, vermicomposting, pertanian organik, demplot 


\section{PENDAHULUAN}

Program Kemitraan Masyarakat (PKM) Kelompok Pemanfaat Kohe di Desa Cibodas dan Kelompok Petani Organik di Desa Cisondari, Kecamatan Pasirjambu, Kabupaten Bandung, merupakan kegiatan community development (pengembangan masyarakat). Cavaye (2015) mendefinisikan pengembangan masyarakat adalah suatu proses yang dilakukan oleh anggota masyarakat. Proses pengembangan masyarakat lokal ini bukan sekedar menciptakan lapangan kerja, meningkatkan pendapatan atau membangun infrastruktur saja, namun juga membantu masyarakat menjadi lebih baik secara fundamental dan mampu mengelola perubahan.

Desa Cibodas dan Desa Cisondari terletak di Kecamatan Pasirjambu Kabupaten Bandung. Kedua desa tersebut memiliki lokasi yang saling bersebelahan satu sama lain. Sebagian besar mata pencaharian penduduk kedua desa tersebut adalah bertani dan berternak sapi perah. Populasi ternak sapi perah di Desa Cibodas merupakan populasi yang terbesar di wilayah Kecamatan Pasirjambu. Dampak dari peternakan sapi adalah adanya limbah kotoran hewan (kohe) yang berpotensi menghasilkan gas metana $\left(\mathrm{CH}_{4}\right)$ sebagai salah satu gas rumah kaca (GRK). Selain itu, apabila dalam penanganannya selama ini kohe dibuang langsung ke sungai, maka dapat mencemari sungai secara langsung.

Vermicomposting, adalah salah satu alternatif pengolahan kohe sapi menjadi pupuk organik dengan menggunakan cacing tanah sebagai mesin pengolah limbah.Menurut Danilo (2017), teknologi vermicompostingmemiliki beberapa keunggulan disamping menghasilkan pupuk organik berkualitas (kascing), juga menghasilkan biomasa cacing sebagai sumber protein. Pupuk kascing yang dihasilkan memiliki karakteristik pupuk lebih aman bagi kesehatan petani dibandingkan dengan penggunaan kohe ayam tanpa perlakuan apapun (mentah), yang saat ini digunakan oleh petani disekitar.Pertanian dengan menggunakan kascing dapat dikategorikan pertanian ramah lingkungan dan berkelanjutan, namun sampai saat ini masyarakat tani belum terbiasa menggunakan pupuk kascing, dikarenakan belum tersedianya kascing secara kuntinyu dan memenuhi kebutuhan, serta kurangnya pengetahuan masyarakat tani didalam hal penggunaan dan memproduksi pupuk kascing.

Tujuan utama daripengabdiankepadamasyarakatiniadalahmemberikan pengetahuan dan praktik kepada kelompok peternak sapi perah, kelompok tani dan buruh ternak, dalam hal:

1. Mengoptimalkan pengolahanlimbah/kotoran hewan (sapi)melalui pemanfaatan kohe dengan teknologi

biogasdanvermicompostuntukmenghasilkanbiogasdanpupukkascing (pupukramah lingkungan)

2. Menyediakan dan memenuhi kebutuhan energi (bahan bakar) dan stock pupuk ramah lingkungan untuk lahan pertanian penduduk desa Cibodas dan Cisondari

3. Mengembangan pertanian ramah lingkungan dalam upaya meningkatkan kualitas hasil pertanian dan meningkatkan kualitas lahan. 
4. Memberi alternatif usaha pada masyarakat Cibodas dan Cisondari untuk dapat menigkatkan taraf kehidupannya dan menjadi lebih sejahtera

Penerapan teknologi, ilmu pengetahuan dan perubahan masyarakat khususnya dalam memanfaatkan kohe dengan proses vermicomposting, dan menjalankan pertanian dengan low input dari luar serta praktek pengamanan kualitas lingkungan, telah dilakukan dengan rangkaian kegiatan, yaitu memberikan pelatihan di kelas, praktek lapang dan demplot (demonstration plot),dan rembug desa. Sehingga memebrikan pengalaman belajar yang mendalam di masyarakat dan mendapatkan dukungan dari pimpinan dan pemangku kepentingan di wilayah mitra.Metode penyuluhan seperti FocusGroup Discussion (FGD) dan demonstrasi plot adalahbeberapa metode untuk mengintroduksi hasil penelitianke dalam praktek pertanian sesungguhnya di tingkat petani. Penyuluhan adalah metode efektif untuk mengkomunikasikan pengetahuan dan keterampilan(Hindersah dkk, 2016).

Rumusan masalah yang ada di wilayah mitra dapat dilihat pada Gambar 1, yang menjelaskan permasalahan yang ada di wilayah mitra dan solusi yang ditawarkan, dengan outcome yang diharapkan adalah tercapainya lingkungan yang bersih, tersedianya pupuk organik ramah lingkungan yang berasal dari lingkungan sendiri, serta adanya sumber penghasilan tambahan bagi masyarakat.

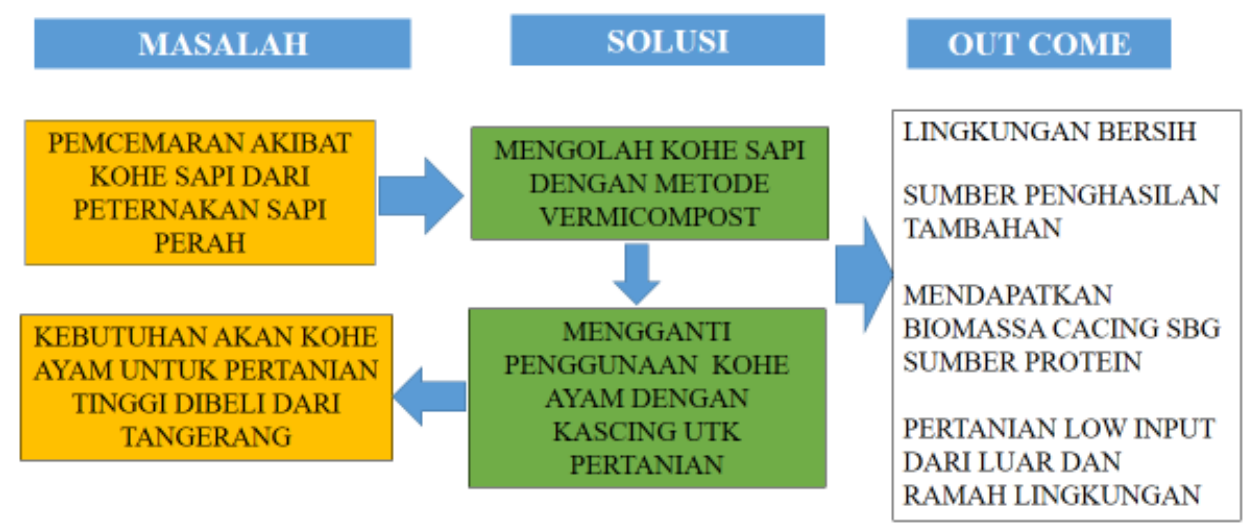

Gambar 1. Masalah dan Usulan Solusi

\section{METODE PELAKSANAAN}

Kegiatan PKM dilakukan di Kampung Papak Manggu,Desa Cibodas untuk kegiatan pemanfaatan kohe sapi dan di kampung Pangkalan Mekar, Desa Cisondari untuk pertanian organik, dengan waktu pelaksanaan dari bulan Maret sampai dengan September 2018. Mekanisme dan tahapan kegiatandapat dilihat pada Gambar 2.Kegiatan sosialisasi program dan pelatihan dilakukan kepada seluruh anggota kelompok mitra, untuk memperjelas tujuan dan rencana kegiatan PKM, sedangkan kegiatan pelatihan bertujuan untuk membuka wawasan dan pengetahuan anggota kelompok peternak dan petani. Materi yang diberikan meliputi sistem pertanian terpadu, pemanfaatan dan pengolahan kohe, dan pertanian organic. Demplot dan uji coba 
dilakukan untuk kegiatan pembuatan pupuk organik dengan metode vermicompost, dan aplikasi variasi pupuk organik dilahan pertanian dengan beberapa jenis sayuran, seperti wortel, pakcoy dan brokoli.

Demplot dan uji coba tersebut dilakukan untuk memberikan gambaran dan pengalaman bagi petani dan pengelola kohe dalam usaha pupuk organik dan pertanian organik. Monitoring dilakukan saat kegiatan demplot, dilakukan 2 kali selama pembuatan pupuk, penanaman sampai waktu panen. Diskusi kelompok (Focus Group Discussion), dilakukan bagi kelompok petani organik dan pengelola kohe, secara terpisah. Diskusi dilakukan setelah panen, untuk membahas hasil panen, menggali pengalaman dan masukandari petani dan pengelola kohe. Kegiatan rembug desa bertujuan untuk melaporkan hasil kegiatan yang telah berlangsung kepada pimpinan desa, tokoh masyarakat dan pengurus kelompokagar mendapatkan dukungan dari pemegang kepentingan dalam pengembangan ekonomi Desa, serta menggali masukan dari peserta.

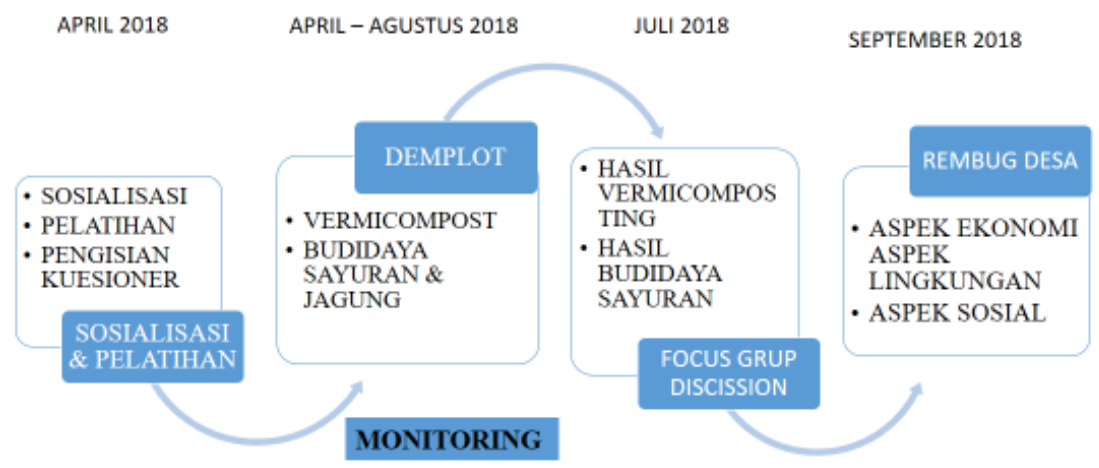

\section{HASIL DAN PEMBAHASAN}

\section{Gambar 2. Skema Diagram Kegiatan PKM}

\subsection{Hasil Kegiatan Pelatihan dan Tanggapan Peserta Pelatihan}

Sosialisasi dan pelatihan dilaksanakan selama 2 hari, meliputi penjelasan program, pelatihan dengan materi pertanian terpadu, pengelolaan kohe dan pertanian organik. Pada hari kedua, dilakukan praktik pembuatan pupuk dari kohe dengan menggunakan bioactivator, serta pembuatan pupuk dengan teknologi vermicomposting. Dalam pelatihan ini dilakukan jajak pendapat kepada seluruh peserta.Setelahmengikuti pelatihan, kepada peserta dibagikan kuesioner. Jumlah pesertasosialisasi dan pelatihan 25 orang, yang terdiri dari delapan peternak, sepuluh petani dan tujuh pengelola kohe. Berdasarkan hasil yang diperoleh, dapat disimpulkan bahwa:

\section{A. Peternak}

Sebagian besar peternak belum mengolah kotoran hewannya, hanya ditumpuk disebelah kandang dan sebagian besar peternak belum mengenal teknologi vermicomposting, hanya ada beberapa orang yang sudah mengenal dari pelatihan.Peternak tertarik melaksanakan pengolahan kohe menjadi pupuksepanjang ada pasarnya. 


\section{B. Petani}

Petani sudah terbiasa melakukan pertanian organik dengan menggunakan kotoran ayam tanpa fermentasi ataupun pengolahan terlebih dahulu. Petani pernah memproduksi kompos dari kotoran hewan (kohe), tetapi dirasa tidak praktis dan lama, serta memerlukan biaya. Petani mau menggunakan pupuk organic dari kascing sepanjang tersedia dan harganya tidak mahal. Saat ini petani membeli kohe ayam dari wilayah Tangerang dengan harga $\mathrm{Rp} 500 / \mathrm{kg}$.

\section{Calon Pemanfaat Kotoran Hewan (Kohe)}

Calon pemanfaat kohe adalah anggota kelompok yang sebelumnya bekerja serabutan, membantu peternak dalam mengurus ternak, mengambil rumput dan membersihkan kadang dan menumpuk kohe di sebelah kandang. Sebagian dari mereka pernah memproduksi kompos dari kohe sapi namun saat ini tidak ada pasar/pembeli. Mereka bersedia mengelola kohe sepanjang ada pasarnya.

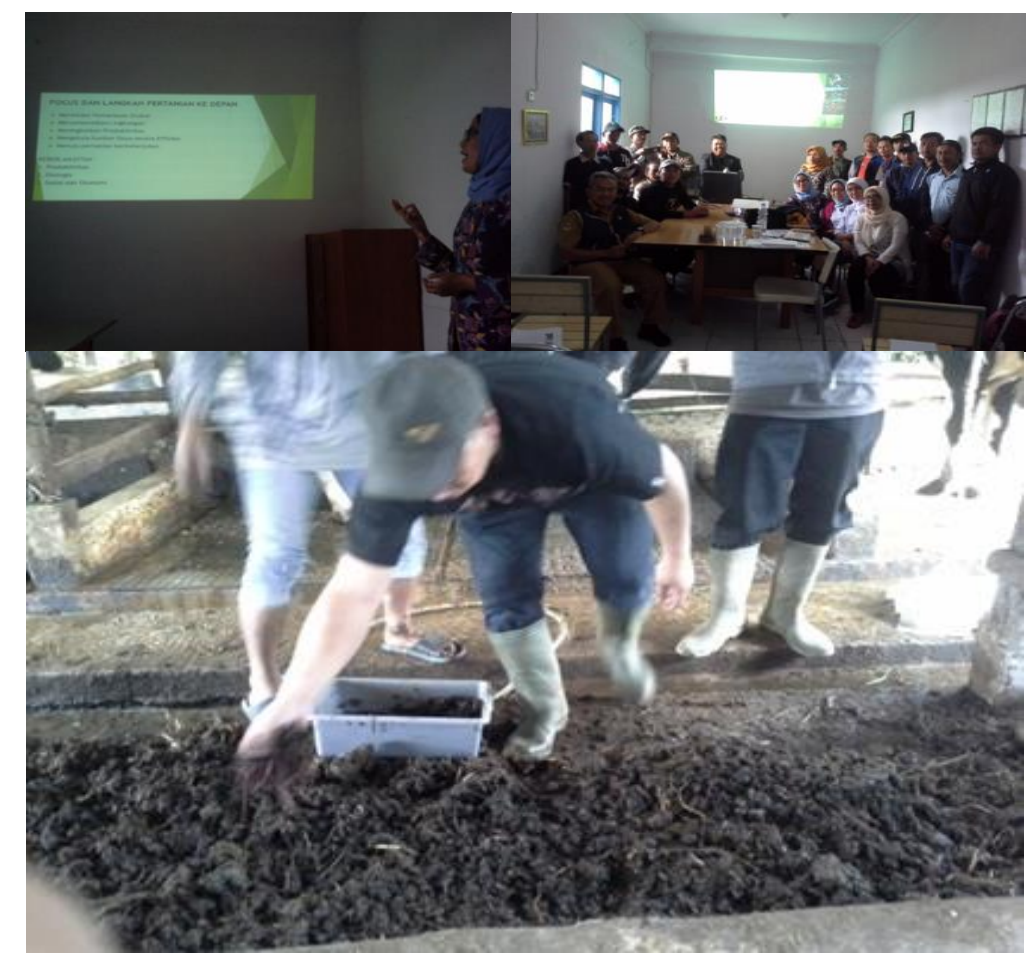

Gambar 3. Pelatihan dan Praktik Pembuatan Pupuk Organik

\subsection{Hasil Uji Coba Demplot}

Demplot dilakukan untuk kegiatan pembuatan pupuk organik dengan metode vermicomposting dan aplikasi variasi pupuk organik di lahan pertanian dengan beberapa jenis sayuran yaitu wortel, pakcoy dan brokoli. Uji coba demplot ini dilakukan untuk memberikan gambaran dan pengalaman bagi petani dan calon pengelola kohe dalam 
usaha pupuk organic dan pertanian organic. Monitoring kegiatan uji coba demplot dilakukan 2 kali selama pembuatan pupuk, penanaman sampai waktu panen.

\subsubsection{Evaluasi Proses dan Hasil Vermicomposting}

Demplot untuk proses vermicomposting dilaksanakan di Kampung Papak Manggu dan Desa Cibodas. Di lokasi tersebut terdapat kandang sapi koloni, dengan jumlah sapi dewasa 5 ekor.Bedeng/rumah cacing menggunakan kandang sapi yang kosong (kebetulan ada beberapa kandang sapi yang tidak digunakan).Ukuran Bedeng 1.7 x 2.7 x $0.2 \mathrm{~m}$. dengan jumlah cacing yang dimasukkan awal adalah $25 \mathrm{~kg}$.Bedeng/ tempat tinggal cacing, kohe dari kandang sapi langsung ditebar, kemudian cacing dimasukan ke dalam bed, dan di beri pakan (bagian atas bed) dengan kohe cair sebanyak 6 ember/mg, setiap akan memberi pakan cacing, terlebih dahulu dilakukan menipiskan tinggi bed, dengan mengambil bagian yang sudah warna hitam, yang di sebut Kascing (pupuk).Setelah bed berumur 1 bulan, dibuat bed baru 2 buah, dan mencampur dengan 1/3 isi bed dari bed pertama, dengan tujuan memberikan stater, yang sduah berisi cacing. Setelah 5 bulan bekerja, jumlah bed mencapai 16 bed, kemudian di bongkar atau dipanen menghasil sebagai berikut:

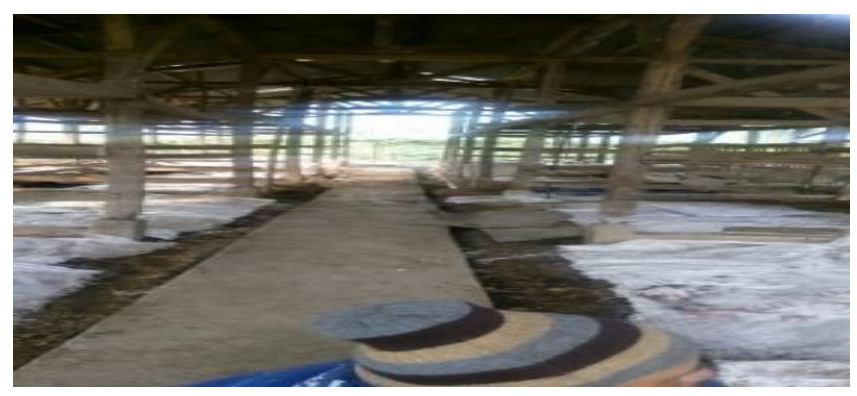

Gambar 3. Proses Vermicompostingdi Kampung Papak Manggu Desa Cibodas

Hasil analisis laboratorium terhadapkascing dibaningkan dengan kohe ayam mentah dan kualitas tanah dapat dilihat pada Tabel 1.

Tabel 1. Kualitas Pupuk Organik

\begin{tabular}{|lcccc|}
\hline PARAMETER & $\begin{array}{c}\text { Pupuk } \\
\text { organik * }\end{array}$ & $\begin{array}{c}\text { Pupuk } \\
\text { organik*** }\end{array}$ & $\begin{array}{c}\text { Kohe ayam } \\
\text { tanpa } \\
\text { perlakukan }\end{array}$ & Tanah \\
\hline pH 1:5 H2O & $4-9$ & 6.36 & 8.7 & 4.45 \\
\hline $\begin{array}{l}\text { C-Organik } \\
\text { (Gravimetri) } \\
(\%)\end{array}$ & Min 15 & 25.06 & 26.76 & 4.53 \\
\hline Rasio C/N & $15-25$ & 16.89 & 14.3 & - \\
\hline $\begin{array}{l}\text { P2O5 + K2O + } \\
\text { N (unsur hara) }\end{array}$ & Min 4 & 3.19 & 13.43 & 3.85 \\
\hline $\begin{array}{l}\text { Kadar Air (\%) } \\
\text { *Peraturan Menteri pertanian No 70/Pementan/SR.140/10/2011 }\end{array}$ & \\
** Vermicompost dari kohe sapi murni (100\%) & & \\
\hline
\end{tabular}


Bila dibandingkan dari sis kualitas unsur hara makro, kohe ayam tanpa fermentasi lebih bagus disbanding dengan kandungan unsur hara kascing kohe sapi, namun kualitaas kascing jauh lebih nagus dibandingkan dengan kualitas lahan yang tersedia. Hasil analisa laboratorium produksi kascing dengan bahan baku kohe murni 100\%, munjukan hampir semua parameter memenuhi standar kualitas pupuk organik berdasarkan Peraturan Menteri Pertanian no 70 /Permentan/SR.140/10/2011 (Tabel 1), kecuali unsur hara makro masih dibawah minimal yaitu $3.19 \%$ (seharusnya diatas 4\%). Kondisi lahan pertanian di desa Cisondari sangat miskin unsur karbon organik nya, sangat perlu penggunaan pupuk organik.

\subsubsection{Hasil Demplot Pertanian Organik}

Agar petani mau menggunakan pupuk kascing, maka dilakukan demplot penerapan pupuk kascing dan kohe ayam pada tanaman wortel (Daucus carotaL), pakcoy (Brassica rapa), dan brokoli (Brassica oleracea L). Demplot dibuat dengan ukuran 0,8 x 8 meter dengan ulangan tiga kali dan jarak tanam untuk tanamanwortel 10x20 $\mathrm{cm}$, pakcoy 20x20 cm, dan jarak tanam brokoli 50x70 cm. Dosis pupuk kohe ayam maupun kascing masing-masing ditambahkan ke bedengan sebanyak $5 \mathrm{~kg} / \mathrm{m}^{2}$ atau $32 \mathrm{~kg}$ untuk setiap bedengnya atau 5 ton/ha. Pada Gambar 4a, $4 \mathrm{~b}$ dan $4 \mathrm{c}$ dapat dilihat pertumbuhan tanaman brokoli, wortel, dan pakcoy dengan penggunaan pupuk kascing.

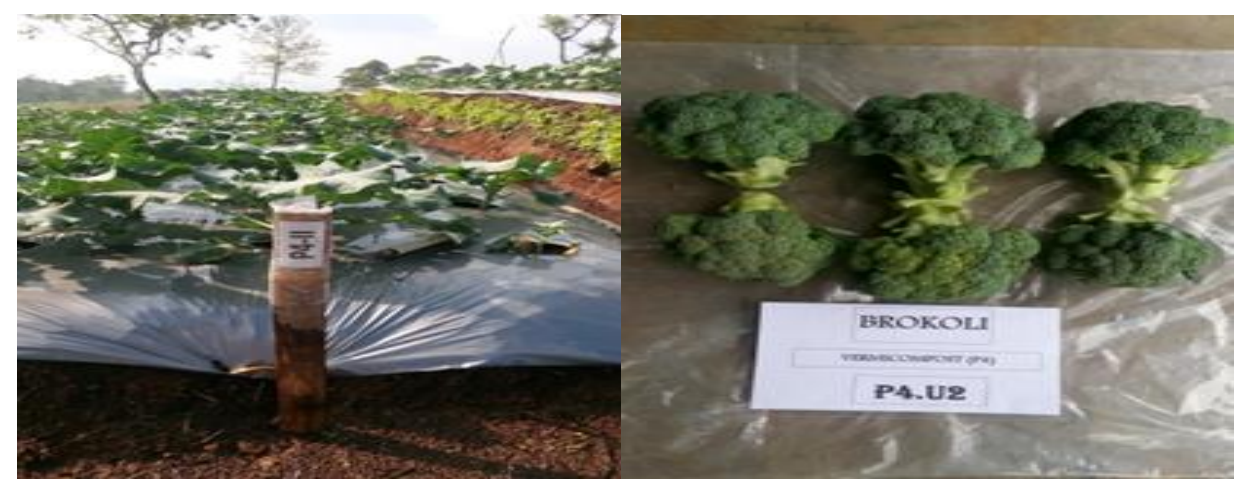

Gambar 4 a : Pertumbuhan \& hasil Brocoli

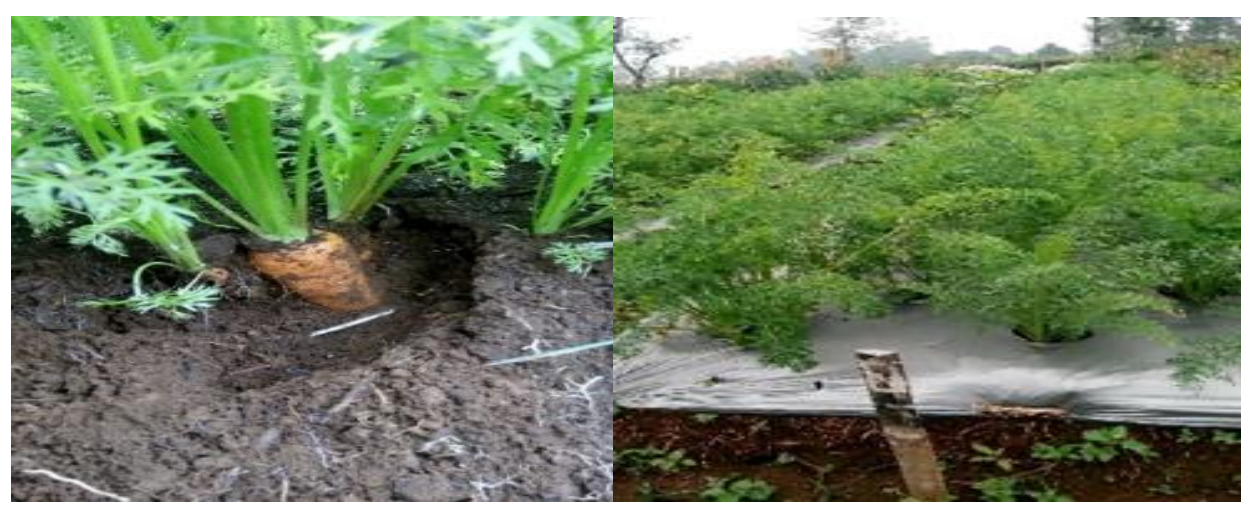

Gambar b : Pertumbuhan \& hasil Wortel 


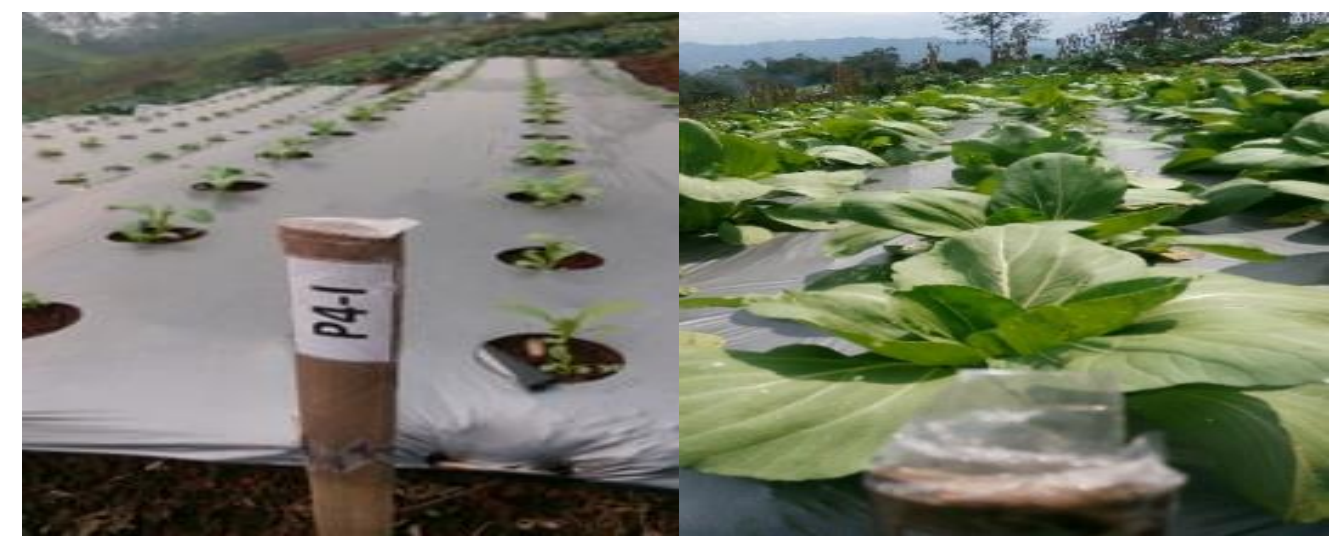

Gambar 4 c: Pertumbuhan \& hasil Pakcoy

Pertumbuhan tanaman Brocoli, Wortel dan Pakcoy dengan menggunakan pupuk vermikompos cukup bagus pertumbuhan maupun hasilnya. Hasil yang didapat dari penanaman diatas, bahwa berat basah pada setiap tanaman yang diberi pupuk kohe dibandingkan dengan tanaman tanpa pupuk hasilnya lebih tinggi.

Tabel 2. Hasil Berat Basah pada Tanaman yang Dipupuk dan yang Tidak Dipupuk

\begin{tabular}{|l|c|c|c|}
\hline \multirow{2}{*}{\multicolumn{1}{c}{ Perlakuan }} & \multicolumn{3}{c}{ Produksi (ton/ha) } \\
\cline { 2 - 4 } & Wortel & Pakcoy & Brokoli \\
\hline Kohe Ayam & 24.6 & 56.1 & 10 \\
\hline Kohe Ayam dg Fermentasi & 34 & 49.1 & 9.5 \\
\hline Vermicompost & 17.9 & 48.7 & 8.5 \\
\hline Tanpa Pemupukan & 12.9 & 21 & 2.6 \\
\hline
\end{tabular}

Dari Tabel 2 terlihat bahwa pemberian pupuk vermicompost pada tanaman Wortel, Pakcoy dan Brokoli lebih kecil dibandingkan dengan pemberian pupuk kohe ayam dan kohe ayam fermentasi. Perbedaan tidak terlalu tinggi apabila dibandingkan dengan penanaman tanpa pemberian pupuk. Pemberian pupuk vermikompos pada PKM ini tidak bisa hanya dilihat hasil berat basah yang kecilnya daripada pemberian pupuk kohe ayam, tapi harus dilihat dari manfaatnya. Dengan pemberian vermikompost, kohe sapi yang tadinya kurang dimanfaatkan, bahkan menjadi limbah, sekarang dapat dimanfaatkan sebagai bahan pupuk organic. Selain didapat pupuk vermikompos, penggunaan kascing dapat menghasilkan cacing yang dapat dijual, dan juga dapat memberikan peluang usaha bagi pengelola/pemanfaat kohe.

\subsection{Hasil Focus Grup Discussion}

Focus group discussion dilakukan dua kali, pertama dengan kelompok tani, dan kelompok peternak dan calon pengelola kohe. FGD bertujuan untuk membahas hasil panen vermicompost dan hasil panen sayuran serta masalah-masalah yang dihadapi, untuk mencari solusi dan langkah ke depan.Dari hasil FGD diperoleh kesepakatan kelompokakan melanjutkan pemanfaataan kohe dengan teknologi vermicompost, yang mana hasil nya berupa pupuk kascing di beli harga $\mathrm{Rp} 250 / \mathrm{kg}$ dan cacing hidup dengan 
harga $\mathrm{Rp} \mathrm{10.000/kg} \mathrm{ditingkat} \mathrm{pengelola.} \mathrm{Dan} \mathrm{melanjutkan} \mathrm{penggunaan} \mathrm{pupuk} \mathrm{kascing}$ untuk tanaman sayuran secara bertahap, sesuai ketersediaan pupuk kascing.

\subsection{Hasil Rembug Desa}

Tujuan Rembug Desa, adalah untuk mendapatkan kesepakatan langkah yang akan diambil dalam rangka mewujudkan Pengembangan Masyarakat. Rembug desa dihadiri oleh Kepala desa dan para tokoh masyarakat yang berperan dalam masyarakat. Dalam rembug desa ini diawali dengan pengarahan Kepala desa, dilanjutkan dengan penyampaian kegiatan pengabdian masyarakat yang telah dilaksanakan dan temuan serta usulan langkah selanjutnya. Diskusi meliputi 3 aspek utama dalam pengembangan massyarakat yaitu Aspek ekonomi, Aspek Sosial dan Aspek lingkungan. Pada gambar 5 dapat dilihat suasana saat rembug desa. Peserta diajak aktif berpatisipasi memberikan masukan terkait langkah langkah yang akan dilakukan dalam pengembangan masyarakat.
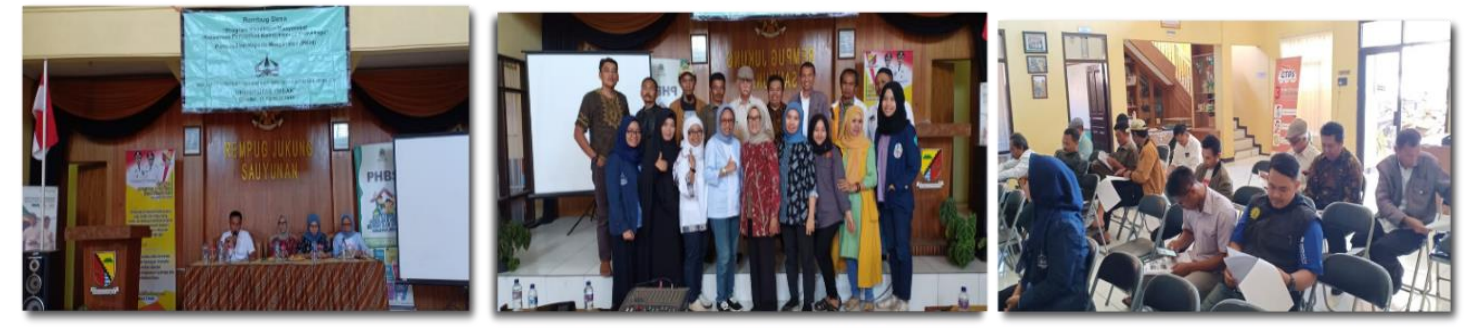

Gambar 5 Kegiatan Rembug Desa

Hasil yang disepakati pada rembug desa adalah, memanfaatkan lahan Desa di kampong Injeman seluas $30 \mathrm{Ha}$, menjadi Pusat Kegiatan Masyarakat dengan konsep "Ecovillage"Dalam kegiatannya akan diciptakan usaha pertanian terpaduramah lingkungan berbasis Sapi perah, vermicomposting dan jagung sebagai komoditi unggulan, dengan memberdayaan masyarakat prasejahtera.

\section{SIMPULAN}

Teknologi vermicomposting, merupakan metode yang tepat untuk mengolah kotoran sapi di Desa Cibodas, karena disamping dapat memperbaiki kualitas lingkungan, vermikompos juga dapat memberikan peluang usaha, menyediakan pupuk organik yang dibutuhkan oleh petani dan adanya produk samping yaitu cacing, sebagai penghasilan tambahan. Perubahan kebiaasan dan introduksi teknologi baru pada masyarakat ini sangat efektif dengan menggunakan metode Pelatihan, Demplot, Focus Group Discussion dan dilanjutkan dengan Rembug desa. Hal ini terbukti dengan merjalannya proses pengolahan kotoran sapi dan pemanfaatan pupuk kascing di laha pertanian. Adanya keinginan menindak lanjuti kegiatan yang sudah dirintis ini menjadikan sebuah program Desa, dengan merencanakan dibangunnya Pusat Kegiatan Masyarakat dengan konsep "Ecovillage" 


\section{UCAPAN TERIMA KASIH}

Terimakasih kepada Kementerian Riset, Teknologi dan Pendidikan Tinggi Republik Indonesia yang telah membiayai kegiatan pengabdian kepada masyarakat ini, melalui danahibah Program Kemitraan Masyarakat (PKM) Tahun Anggaran 2017- 2018 dengan Nomor Kontrak: 006/KM/PPM/2018.

\section{DAFTAR PUSTAKA}

Danilo Rogayan Jr, Vermicompost and Vermicompoting https://www.researchgate.net/publication/316988316, May 2017

Edi Indrizal, Focus Group Discussion
http://repo.unand.ac.id/4984/1/Artikel\%20Edi\%20Indrizal.pdf

Hindersah, R dkk, Penggunaan Demonstrasi Plot Untuk Mengubah Metode Aplikasi Pupuk organik pada Lahan Pertanian Sayuran di kota Ambon Dharmakarya: Jurnal Aplikasi Ipteks untuk Masyarakat Vol. 5, No. 1, Mei 2016: 9 -15, ISSN 1410 - 5675 Jim Cavaye, Understading Community Development, Cavaye Community Development,https://www.researchgate.net/publication/265233282_Understanding Community Development, 2015 